\title{
ROMAN DROZD
}

Instytut Historii

Akademia Pomorska w Słupsku

ORCID 0000-0003-0169-7295

\section{OJCIEC ŚWIĘTY JAN PAWEŁ II ORAZ HIERARCHOWIE KOŚCIOLA RZYMSKOKATOLICKIEGO I GRECKOKATOLICKIEGO W PROCESIE POJEDNANIA POLSKO-UKRAIŃSKIEGO}

\author{
Holy Father John Paul II and the hierarchs of the Roman Catholic and Greek \\ Catholic Church in the process of Polish-Ukrainian reconciliation
}

\section{Abstract}

The process of reconciliation between Poles and Ukrainians is hindered by the sense of mutual harm. The need to change this situation was recognised by Pope John Paul II, on whose initiative a dialogue took place between the hierarchs of the Roman Catholic and Greek Catholic Churches. A gesture was made, and conciliatory documents were issued. Following the letter of the Polish bishops to the German bishops of 1965, they adopted the formula "we forgive and ask for forgiveness." The hierarchs were followed by Polish and Ukrainian statesmen, some politicians, the clergy and the faithful. Much has been done, but the process of reconciliation is not yet complete. One obstacle is the habit of parts of Polish and Ukrainian society to see only their own suffering, and not the pain inflicted on the other side.

Keywords: Pope John Paul II, Roman Catholic Church, Greek Catholic Church, dialogue, reconciliation, Poland, Ukraine

\begin{abstract}
Abstrakt
Poczucie wzajemnie wyrządzonej sobie krzywdy utrudnia proces pojednania między Polakami i Ukraińcami. Potrzebę zmiany tego stanu rzeczy dostrzegł papież Jan Paweł II, z którego inicjatywy doszło do dialogu między hierarchami Kościoła rzymskokatolickiego i greckokatolickiego. Wykonano gest i wydano dokumenty pojednawcze. Wzorując się na liście biskupów polskich do niemieckich z 1965 r., przyjęto w nich formułę ,przebaczamy i prosimy o przebaczenie”. W ślad za hierarchami poszli polscy i ukraińscy mężowie stanu,

\footnotetext{
1 Roman Drozd, prof. dr hab., historyk, pracuje w Instytucie Historii Akademii Pomorskiej w Słupsku, rektor tej uczelni w latach 2008-2016, zajmuje się polityką narodowościową w Polsce po 1918 r., położeniem mniejszości ukraińskiej w Polsce, relacjami polsko-ukraińskimi, dziejami Kościoła greckokatolickiego w PRL oraz dialogiem polsko-ukraińskim.E/mail: roman.drozd@apsl.edu.pl.
} 
niektórzy politycy, duchowieństwo i wierni. Zrobiono wiele, ale proces pojednania jeszcze się nie zakończył. Na przeszkodzie stoi niechęć części społeczeństwa polskiego i ukraińskiego, które dostrzega tylko własną krzywdę, a nie widzi bólu zadanego drugiej stronie.

Słowa kluczowe: papież Jan Paweł II, Kościół rzymskokatolicki, Kościół greckokatolicki, dialog, pojednanie, Polska, Ukraina

nalizując na przestrzeni wieków relacje międzysąsiedzkie w Europie, dostrzega się
różne ich aspekty. Dochodziło do współpracy, a nawet sojuszniczej walki z wrogiem,
ale również do wzajemnej niechęci i konfliktów. Na tym tle nie wyróżniają się stosunki pol-
sko-ukraińskie. Obok kart współdziałania, jak to było w wojnie z bolszewikami w 1920 r.,
była również wzajemna wrogość nacechowana brutalnością i wyrządzaniem krzywdy,
zabijaniem swoich sąsiadów tylko dlatego, że byli innej narodowości czy wyznania. Do
najtragiczniejszych wydarzeń doszło w czasie II wojny światowej i w pierwszych latach
po jej zakończeniu. Mordy na ludności polskiej na Wołyniu i w Galicji Wschodniej oraz
deportacja ludności ukraińskiej na Ukrainę sowiecką, a następnie w ramach akcji „Wisła”,
miały i jeszcze mają bardzo poważny wpływ na wzajemne postawy Polaków i Ukraińców².
Wyrządzono wówczas sobie nawzajem olbrzymią krzywdę, która boli po dzień dzisiejszy,
mimo że od tamtych wydarzeń minęło ponad 70 lat. Badania historyków wskazują, że życie
straciło wówczas o wiele więcej Polaków niż Ukraińców, lecz nie da się zważyć krzywdy
i stwierdzić, która bardziej boli. Niemniej zadane sobie wzajemne rany nie zagoiły się
i utrudniają pełną normalizację stosunków między Polakami i Ukraińcami współcześnie.
Zdali sobie z tego sprawę hierarchowie Kościoła rzymskokatolickiego i greckokatolic-
kiego, którzy w imię chrześcijańskiej miłości postanowili rozpocząć proces pojednania
między Polakami i Ukraińcami na płaszczyźnie ,,przebaczamy i prosimy o przebaczenie”3.
Jak stwierdził ks. Stefan Batruch, „Zrozumienie nadrzędności przebaczania nad chęcią
odwetu za doznane krzywdy, jest wezwaniem do przezwyciężenia wszystkiego tego, co
hamuje zbliżenie i często sprowadza się do ciągłego analizowania trudnych okresów we
wspólnych dziejach”. Nie oznacza jednak relatywizacji historii czy też zapominania o tych
tragicznych wydarzeniach i ofiarach. Wręcz przeciwnie mają one uświadamiać obecne

\footnotetext{
2 Wiele prac tej tematyce poświęcił Marek Melnyk m.in.: Aktywność polityczna społeczności ukraińskiej na Warmii i Mazurach, w: Polityczne wymiary etniczności, red. M. Mieczkowska, D. Scholze, Wydawnictwo Dante, Kraków 2009, s. 206-217; Deklaracje o pojednaniu polsko-ukraińskim: próba dialogu pamięci?, w: Aksjologia spoleczno-polityczna: studia i materiaty, red. Z. Kobylińska, M. Melnyk, H. Skorowski, Wydawnictwo Uniwersytetu Kardynała Stefana Wyszyńskiego, Warszawa 2016, s. 187-207; Ekumeniczny wymiar dialogu polsko-ukraińskiego, „Pogranicza. Studia społeczne”, 2011, t. 17, nr 2, s. 84-98; Polacy i Ukraińcy. Pojednani Ewangelia, „Edukacja Humanistyczna”, 2017, nr 2, s. 23-31; Problem badań nad dialogiem i pojednaniem polsko-ukraińskim, w: W cieniu akcji ,Wista”, red. M. Melnyk, Wydawnictwo Uniwersytetu Warmińsko-Mazurskiego, Olsztyn 2008, s. 99-120. Patrz także: Jutro rocznica podpisania deklaracji Kościoła łacińskiego i greckokatolickiego nt. zbrodni wolyńskiej (analiza), https://kair.ekai.pl/depesza/494426/show?q=pojednanie\%20polsko-ukrai\%C5\%84skie (dostęp 30.06.2021).

3 N temat dziejów Kościoła greckokatolickiego w Polsce patrz: I. Hałagida, Między Moskwa, Warszawa i Watykanem. Dzieje Kościoła greckokatolickiego w Polsce w latach 1944-1970, Wydawnictwo „Bazyliada”, Warszawa 2013.

4 S. Batruch, Wspótpraca między Kościolem greckokatolickim i rzymskokatolickim na rzecz pojednania polsko-ukraińskiego, „Peremyśki Archyjeparchialni Widomosti”, 14/2017, cz. 23, s. 49.
} 
i przyszłe pokolenia, że w codziennym życiu należy odrzucić nienawiść, która doprowadza jedynie do wyrządzenia krzywdy drugiej osobie.

Inicjatorem i prekursorem podjęcia działań przez Kościół rzymskokatolicki i greckokatolicki na rzecz polsko-ukraińskiego pojednania stał się papież Jan Paweł II. Z wielkim uznaniem i szacunkiem odnosił się do zwierzchnika Kościoła greckokatolickiego abpa Josyfa Slipego, który 18 lat spędził w łagrach sowieckich i nie wyrzekł się jedności ze Stolicą Apostolską. Na otwarciu synodu biskupów ukraińskich w 1980 r. w Rzymie wypowiedział ważne słowa: „często rozmyślam nad szczególną bliskością Waszego i mego rodzimego narodu”. Bardzo wymowny był gest, jaki Jan Paweł II wykonał podczas swojej pielgrzymki do Polski w 1987 r., kiedy to, łamiąc uzgodniony protokół wizyty, odwiedził i pomodlił się w cerkwi oo. bazylianów w Warszawie. Wspomniane gesty oraz wiele innych mniejszych, ale nie mniej ważnych, ze strony papieża było wiele. Świadczyły one o chęci Ojca Świętego doprowadzenia do zbliżenia miedzy oboma Kościołami i pojednania między Polakami i Ukraińcami. Zwierzchnik Kościoła greckokatolickiego abp Swiatosław Krawczuk 26 sierpnia 2019 r. na Jasnej Górze, mówiąc o Janie Pawle II, stwierdził: „To on był inspiratorem tego procesu. To on po raz pierwszy po zakończeniu II wojny światowej uczestniczył w spotkaniach episkopatu Polski i biskupów greckokatolickich naszej diaspory. To on inspirował proces pojednania, który chcemy kontynuować" 6 .

$\mathrm{Na}$ uwagę z początku lat osiemdziesiątych XX w. zasługuje wręcz pionierskie wydarzenie, jakim była liturgia w intencji polsko-ukraińskiego pojednania. Odbyła się ona 3 czerwca 1984 w Leśnej Podkowie z inicjatywy proboszcza parafii rzymskokatolickiej ks. Leona Kantorskiego z udziałem intelektualistów polskich i ukraińskich. Witając zebranych, proboszcz wypowiedział znamienne słowa nawiązujące do listu biskupów z 1965 r.: „Jest to wspólna modlitwa o pojednanie polsko-ukraińskie. Chcemy przebaczyć krzywdy nam wyrządzone i chcemy prosić o przebaczenie krzywd, które myśmy wyrządzili. [...] my dzisiaj tutaj - maleńki kościół, maleńka wspólnota rzymskokatolicka Polaków z tą małą wspólnotą greckokatolicką Ukraińców - chcemy zapoczątkować w zakresie naszych skromnych możliwości modlitwę o pojednanie i samo pojednanie"7.

Z kolei o. Jozafat Romanyk będący wikarym generalnym dla grekokatolików na obszar północnej Polski w wygłoszonej wówczas homilii powiedział: „Zebraliśmy się tutaj, w tej świątyni, po to, aby przeżyć bardzo ważną chwilę. Nie żeby dyskutować, przekonywać się wzajemnie, szukać winnych. Jesteśmy tu w tym celu, by w domu naszego wspólnego Ojca złożyć Mu bezkrwawą ofiarę, tę samą, którą kiedyś w krwawy sposób złożył Mu Jego Syn Jednorodzony. I po to jeszcze tu zebraliśmy się, by w tej ofierze zaczerpnąc siłę do pojednania i wzajemnego przebaczenia. Tak jak pierwsza krwawa Ofiara stała się początkiem pojednania ludzkości z Bogiem - tak ta, dzisiejsza, powinna stać się znakiem i źródłem pojednania nas, braci, dzieci tego samego Ojca niebieskiego, źródłem i początkiem

\footnotetext{
Ibidem, s. 51.

6 J. Borkowicz, Święty Jan Pawet patronem polsko-ukraińskiego pojednania. Stan posiadania, ryzyko i wyzwania projektu, w: Polacy i Ukraincy. Komunikacja - Dialog - Pojednanie, red. M. Melnyk, Wydawnictwo Collegium Columbinum, Kraków 2020, s. 135.

7 Stowo wstępne wygłoszone przez ks. Leona Kantorskiego, proboszcza parafii rzymskokatolickiej pw. Św. Krzysztofa w Podkowie Leśnej, na spotkaniu intelektualistów polskich i ukraińskich przed majaca się tam odbyć msza święta w obrządku greckokatolickim, z 3 VI 1984 r., „Peremyśki Archyjeparchialni Widomosti”, 14/2017, cz. 23, s. 102 (dok. 2).
} 
pojednania naszych narodów - polskiego i ukraińskiego"8. Na zakończenie Mszy świętej uczestnicy przyjęli „Memoriał w sprawie polsko-ukraińskiego pojednania” oraz skierowali listy do Jana Pawła II, zwierzchnika Kościoła greckokatolickiego kard. Josyfa Slipyja, prymasa Józefa Glempa oraz polskich biskupów, w których informowali o odbytej modlitwie oraz prosili o wsparcie działań na rzecz polsko-ukraińskiego pojednania9 ${ }^{9}$ Niewątpliwie ta oddolna inicjatywa pokazywała, że jest możliwa wspólna modlitwa Polaków i Ukraińców oraz wzajemne przebaczenie wyrządzonych sobie krzywd. Uświadamiała także hierarchom obu obrządków, że już czas zaangażować się w proces polsko-ukraińskiego pojednania. Jeżeli udało się pojednanie niemiecko-francuskie i polsko-niemieckie, to dlaczego nie miałoby udać się to polsko-ukraińskie. W dążeniu do niego przyjęto chrześcijańską formułę „przebaczamy i prosimy o przebaczenie”, gdyż jest wyrazem miłości do bliźniego i nie jest wymierzona w jego godność. Warto dodać, że wspólna modlitwa w Podkowie Leśnej odbyła się na kilkanaście dni przed wizytą w Polsce greckokatolickiego abpa Myrosława Marusyna - sekretarza Kongregacji Kościołów Wschodnich, który w dniach 21 czerwca 7 lipca 1984 r. odwiedził parafie greckokatolickie oraz odbył szereg rozmów z biskupami polskimi na czele z prymasem J. Glempem. Ich celem było zamanifestowanie troski samego Papieża oraz hierarchów greckokatolickich o los ich wiernych w Polsce ${ }^{10}$.

Okazją do pełnego wybrzmienia idei pojednania tych dwóch narodów było zbliżające się milenium chrztu Rusi Kijowskiej. W trakcie synodu biskupów katolickich w Rzymie w 1987 r. doszło 8 i 17 października do spotkań hierarchów polskich z greckokatolickimi. Trudno obecnie powiedzieć, kto był ich inicjatorem, ale należy przypuszczać, że musiały się one odbyć, jeżeli nie z inicjatywy, to na pewno za wiedzą Jana Pawła II. Fakt, że pierwsze spotkanie odbyło się w Papieskim Kolegium Polskim wskazywałby, że stroną zapraszającą byli biskupi polscy. Prymas Józef Glemp w wystąpieniu na tym spotkaniu krótko przedstawił trudną sytuację rzymskich katolików na Ukrainie oraz rozwój Kościoła greckokatolickiego w Polsce, wskazując, jak wiele jest jeszcze do zrobienia. Nawiązując do zbliżających się obchodów jubileuszu 1000-lecia chrześcijaństwa na ziemiach ukraińskich, wyraził nadzieję na wspólne ich obchody na Jasnej Górze. Była to bardzo ważna deklaracja dla biskupów ukraińskich, którzy, nie mogąc świętować jubileuszu na Ukrainie, starali się to uczynić jak najbliżej granicy. Jasna Góra jest miejscem symbolicznym, ważnym dla katolików i stwarza możliwość wspólnej modlitwy przed ikoną Matki Boskiej Częstochowskiej, która ze względu na swe pochodzenie jedna Polaków i Ukraińców. Zapewne dlatego prymas wypowiedział ważne słowa w duchu pojednania: „Nie chcemy poruszać historii, w której na pierwszy plan wybijają się sprawy bolesne. Taka jest tendencja patrzenia na nasze wspólne dzieje. Może kiedyś odkryjemy w naszej historii dobre karty, bo i takie były. Byli w naszej historii Ukraińcy, którzy kochali Polaków, i byli Polacy, którzy kochali Ukraińców. Dziś jednak przygniata nas jakby nawyk narzekań, uprzedzeń oraz wspomnienia łez, a także krwi. Nie wolno nam podejmować licytacji, kto komu więcej krzywd wyrządził. Do niczego to nie doprowadzi. Szczególnie my, duchowni, winniśmy wiedzieć, że gojących się ran nie wolno

\footnotetext{
Homilia wygłoszona przez o. Jozafata Romanyka OSBM podczas mszy świętej w obrządku greckokatolickim, zorganizowanej z inicjatywy ks. Leona Kantorskiego i tamtejszych parafia wyznania rzymskokatolickiego, z 3 VI 1984 r., „Biuletyn Ukrainoznawczy”, 2013-2014, nr 16/17, s. 128 (dok. 3).

Patrz: „Biuletyn Ukrainoznawczy”, 2013-2014, nr 16/17, s. 132-140 (dok. 5-9).

10 R. Drozd, Polityka władz wobec ludności ukrainskiej w Polsce w latach 1944-1989, Wydawnictwo Tyrsa, Warszawa 2001, s. 312-113.
} 
drapać. Pomyślmy, że mógł być ktoś trzeci, co nas wzajemnie podburzał, by wygrać własne interesy"11. Z kolei zwierzchnik Kościoła grekokatolików kard. Myrosław Lubacziwskij odniósł się do trudnej sytuacji duchownych i wiernych tego obrządku na Ukrainie oraz zaakcentował swoja troskę o grekokatolików w Polsce, a także zapytał o możliwość obchodów Tysiąclecia Chrztu w Polsce ${ }^{12}$. Brak odniesienia się kard. Lubacziwskiego do słów prymasa o pojednaniu może świadczyć, że delegacja ukraińska była tym zaskoczona, nieprzygotowana na taką ewentualnośćc ${ }^{13}$.

Inaczej strona ukraińska zachowała się na kolejnym spotkaniu biskupów polskich i ukraińskich 17 października 1987 r. w Ukraińskim Kolegium św. Jozafata w Rzymie. Kard. M. Lubacziwskij w swoim powitalnym wystąpieniu podziękował prymasowi za gotowość „zapomnienia wszystkich bolących urazów i tego, co nasze narody tak często dzieliło w ciągu ich historii, a co nieraz było od nich całkowicie niezależne"14, a następnie, nawiązując do listu Episkopatu polskiego do niemieckiego, powiedział: „Stojąc dzisiaj u progu wielkiego jubileuszu Tysiąclecia Chrztu Rusi-Ukrainy, istnienia Cerkwi Kijowskiej [...] również i my - hierarchia Ukraińskiej Katolickiej Cerkwi, wyciągamy braterską dłoń do Braci Polaków na znak pojednania, przebaczenia i miłości’’15. Odnosząc się do tych słów, prymas. J. Glemp stwierdził: „Pan Jezus dał pouczenie wszystkim tym, którzy zbliżają się do ołtarza, aby wpierw pojednali się ze swymi braćmi. «Jeśli [...] wspomnisz, że brat twój ma coś przeciwko tobie, zostaw tam dar swój przed ołtarzem, a najpierw idź i pojednaj się z bratem swoim» (Mt 5,23-24). Jesteśmy winowajcami wobec Boga, bo jesteśmy grzeszni, jesteśmy winowajcami wobec braci, bo za mało w nas miłości. Jesteśmy winowajcami wobec Was, Bracia Ukraińcy, bo nie umieliśmy nauki wynikającej z chrztu świętego wprowadzić w życie. [...] mamy winy jedni wobec drugich. A gdzie są winy, tam trzeba mówić: «Odpuść nam nasze winy, jako i my odpuszczamy»" "16.

Nie wiemy, czy hierarchowie zdawali sobie wówczas wagę z wypowiedzianych słów. Wychodząc z założenia chrześcijańskiej miłości do bliźniego oraz zapoczątkowania w 1965 r. historycznego procesu pojednania między Polakami i Niemcami przed nadchodzącym jubileuszem Tysiąclecia Chrztu Polski, uznali, że zbliżający się jubileusz tysiąclecia chrześcijaństwa na ziemiach ukraińskich jest doskonałą okazją do zapoczątkowania polsko-ukraińskiego pojednania. Swoimi deklaracjami określili także płaszczyznę pojednania na zasadzie „przebaczamy i prosimy o przebaczenie”, bez szukania winnych, a raczej bez obarczania

\footnotetext{
11 Przemówienie ks. abp. Józefa Glempa na spotkaniu duchowieństwa polskiego i greckokatolickiego w Papieskim Kolegium Polskim , z 8 X 1987 r., „Peremyśki Archyjeparchialni Widomosti”, 14/2017, cz. 23, s. 114 (dok. 4).

12 Przemówienie ks. kard. Myrosława Lubacziwskiego na spotkaniu duchowieństwa polskiego i ukraińskiego w Papieskim Kolegium Polskim, z 8 X 1987 r., „Biuletyn Ukrainoznawczy”, 2013-2014, nr 16/17, s. 147-149 (dok. 12).

13 Na taką ewentualność wskazuje M. Melnyk, Milenium chrztu Rusi Kijowskiej w procesie pojednania polsko-ukraińskiego, w: Polacy i Ukraińcy..., dz. cyt., s. 102-103.

14 Przemówienie kard. M. Lubacziwskiego w Ukraińskim Kolegium św. Jozafata w Rzymie podczas spotkania biskupów polskich i ukraińskich, z 1 X 1987 r., „Peremyśki Archyjeparchialni Widomosti”, 14/2017, cz. 23, s. 124 (dok. 6).

15 Ibidem, s. 124.

16 Przemówienie prymasa J. Glempa w Ukraińskim Kolegium św. Jozafata podczas spotkania biskupów polskich i ukraińskich, z 17 X 1987 r., ,Peremyśki Archyjeparchialni Widomosti”, 14/2017, cz. 23, s. 132 (dok. 7).
} 
się wzajemnymi krzywdami ${ }^{17}$. Szkoda, że nie opracowano wówczas wspólnej deklaracji. Jej istnienie dobitniej potwierdzałoby wolę pojednania między obu narodami. Stanowiłaby dokument, do którego mogliby odwoływać się potomni i ci, co zechcieli kroczyć drogą zbliżenia i pojednania polsko-ukraińskiego.

Publicznym miejscem demonstracji wspólnoty obu narodów, także w kategoriach pojednania, stały się obchody jubileuszu Tysiąclecia Chrztu Rusi-Ukrainy na Jasnej Górze, które odbyły się w dniach 10-11 września 1988 r. Hierarchowie obu Kościołów oraz wierni rzymskokatoliccy i grekokatoliccy wspólnie modlili się i uczestniczyli w uroczystościach towarzyszących ${ }^{18}$. Był to swoisty wyraz, że oba narody mogą tworzyć jedną katolicką wspólnotę. Wydarzenie to uświadamiało i zachęcało do podejmowania działań pojednawczych także osoby świeckie, zwłaszcza po wygranych przez opozycję wyborach parlamentarnych w czerwcu 1989 r. Na przykład 11 września 1989 r. Wojewódzki Komitet Obywatelski w Krośnie wydał „Oświadczenie o stosunkach polsko-ukraińskich”, w którym w ślad za biskupami, zwracając się do Ukraińców, użyto zwrotu przebaczamy i prosimy o przebaczenie $^{19}$. Z kolei 29 grudnia 1989 r. Komisja ds. Mniejszości Narodowych przy WKO „Solidarność” w Przemyślu wezwała „naród polski i społeczeństwo ukraińskie w Polsce” do pojednania i współpracy oraz apelowała „o potępienie bratobójczych mordów dokonanych przez niektóre ugrupowania tak ukraińskiego, jak i polskiego zbrojnego podziemia" w okresie wojny i po jej zakończeniu ${ }^{20}$. W odpowiedzi na ten apel przedstawiciele społeczności ukraińskiej z Przemyśla 14 stycznia 1990 r. wystosowali list do społeczeństwa polskiego, w którym w imieniu społeczności ukraińskiej żyjącej w Państwie Polskim zwrócono się do Polaków z apelem o pojednanie oraz w nawiązaniu do spotkania biskupów w Rzymie w 1987 r. przywołano słowa ,wybaczamy i prosimy o wybaczenie" 21 .

Bardzo ważną rolę w zbliżeniu polsko-ukraińskim odegrało spotkanie papieża Jana Pawła II z grekokatolikami 2 czerwca 1991 r. w Przemyślu podczas jego kolejnej pielgrzymki do Polski. Odbyło się ono w zupełnie innej sytuacji politycznej w Polsce i w tej części Europy. Rozpadł się blok państw komunistycznych, a i sam Związek Sowiecki uległ rozwiązaniu w 1991 r. Odzyskanie przez Polskę suwerenności poprawiło także położenie mniejszości ukraińskiej, w tym grekokatolików. W połowie stycznia 1991 r. bp J. Martyniak został mianowany ordynariuszem greckokatolickiej diecezji przemyskiej. Tym samym nastąpiło odnowienie jej działalności po deportacji jej hierarchów w 1946 r. Była to swego rodzaju sprawiedliwość dziejowa i znak, że „,dobro zło zwyciężyło”, czyli fiasko planów i działań likwidacyjnych Kościoła greckokatolickiego w Polsce, a jednocześnie zwieńczenie sukcesem ponad 40-letnich starań duchowieństwa i wiernych obrządku greckokatolickiego o swoje

\footnotetext{
17 Szerzej na temat interpretacji obu deklaracji: M. Melnyk, Milenium chrztu Rusi Kijowskiej..., dz. cyt., s. 106109.

18 Jasna Góra: konferencja o dialogu polsko-ukraińskim w 30. rocznicę obchodów millenium chrztu Rusi, https:// kair.ekai.pl/depesza/562775/show?q=melnyk\%20marek (dostęp 30.06.2021).

19 Oświadczenie WKO ,,Solidarność” w Krośnie o stosunkach polsko-ukraińskich, z 11 IX 1989 r., w: Ukraińcy w Polsce 1983-1993. Kalendarium. Dokumenty. Informacje, red. M. Czech, Wydawnictwo Tyrsa, Warszawa 1993, s. 101-102 (dok. 12).

${ }^{20}$ Apel Komisji ds. Mniejszości Narodowych przy WKO „Solidarność” w Przemyślu „, Do narodu polskiego i spoteczeństwa ukraińskiego w Polsce o pojednanie i wspótpracę" z 29 XII 1989 r., w: Ukraińcy w Polsce..., dz. cyt., s. 105-106 (dok. 15).

21 List grupy Ukraińców z Przemyśla do spoleczeństwa polskiego w sprawie pojednania z 14 I.1990 r., w: Ukraińcy w Polsce ..., dz. cyt., s. 107 (dok. 16).
} 
prawa. Odnowienie diecezji oznaczało także możliwość zwrotu byłej katedry greckokatolickiej w Przemyślu, użytkowanej teraz przez oo. karmelitów. Stanowczo temu sprzeciwili się, uzyskując poparcie części mieszkańców i władz Przemyśla ${ }^{22}$. W tej sytuacji planowany ingres biskupa Jana Martyniaka odbył się 13 kwietnia 1991 r. nie w byłej katedrze greckokatolickiej, a w katedrze rzymskokatolickiej. Protestujący byli na tyle nieprzejednani, że nawet nie wpuścili do świątyni papieża Jana Pawła II, który tam chciał się spotkać z grekokatolikami. W tej napiętej sytuacji, aby nie dopuścić do eskalacji sporu, do spotkania doszło 2 czerwca 1991 r. w znajdującym się obok katedry kościele garnizonowym, gdzie odbywały się nabożeństwa greckokatolickie. Wówczas papież podniósł go do rangi katedry i przekazał na 99 lat Kościołowi greckokatolickiemu ${ }^{23}$.

Panująca atmosfera wbrew pozorom skłaniała do wykonania gestu pojednania. W tym nasilającym się konflikcie potrzebne było wezwanie do opamiętania się i przypomnienia, jakimi wartościami powinien kierować się chrześcijanin. Zrobił to Ojciec Święty na spotkaniu z grekokatolikami, wypowiadając słowa: „Jakże serdecznie bym pragnął, bracia i siostry, aby tamte jasnogórskie uroczystości Kościoła greckokatolickiego okazały się pod jeszcze jednym względem prorocze: aby Bóg raczył je przyjąć jako symboliczną pieczęć pojednania i prawdziwego braterstwa Polaków i Ukraińców. Tyle goryczy i udręki przeszły oba nasze narody w ciągu ostatnich kilkudziesięciu lat. Niech to doświadczenie posłuży jako oczyszczenie, które ułatwi spojrzenie z dystansem na dawne spory, pretensje i wzajemne nieufności, a przede wszystkim ułatwi wzajemne przebaczenie dawnych krzywd. Dzisiaj dosłownie wszystko - a przede wszystkim wspólna wiara w Jezusa Chrystusa wzywa do pojednania, braterstwa i wzajemnego szacunku; do szukania tego, co łączy. Wzniecanie dawnych nacjonalizmów i niechęci byłoby działaniem przeciwko chrześcijańskiej tożsamości; byłoby również rażącym anachronizmem, niegodnym obu wielkich narodów. O jakże serdecznie pragnę, aby się wzajemnie miłowali katolicy obydwóch obrządków!"24. Wypowiedziane słowa nie trafiły do wszystkich serc, gdyż uspokojenie sytuacji w Przemyślu okazało się krótkotrwałe ${ }^{25}$.

Działania hierarchów obu obrządków przekładały się na postawy różnych instytucji państwowych, powstających organizacji pozarządowych, jak i fizycznych osób, w Polsce oraz w niepodległej Ukrainie. Oczywiście nie wszystkich. Organizacje kresowe i kombatanckie oraz nacjonalistyczne w Polsce, wychodząc z założenia, że Polacy są wyłącznie ofiarami konfliktu z Ukraińcami, odrzuciły zasadę ,,przebaczamy i prosimy o przebaczenie”, żądając od strony ukraińskiej uznania mordów na ludności polskiej za ludobójstwo i potępienie nie tylko sprawców, ale całego ukraińskiego podziemia niepodległościowego. Na to nie godziła się strona ukraińska, uważając, że ona jest także ofiarą konfliktu z Polakami. Doszło do dwóch odmiennych ocen konfliktu polsko-ukraińskiego w czasie II wojny światowej i lat powojennych. To utrudniło i nadal stanowi podstawową przyczynę braku pojednania się obu

\footnotetext{
22 K. Fedorowicz, Ukraina w polskiej polityce wschodniej w latach 1989-1999, Wydawnictwo Naukowe UAM, Poznań 2004, s. 62-63.

23 R. Drozd, Problem własności byłej katedry greckokatolickiej w Przemyślu w latach 1946-1996, „Scripta Historica", 2018, nr 24, s. 237-253.

24 Przemówienie Ojca Świętego Jana Pawła II do wiernych obrządku greckokatolickiego na spotkaniu z nimi w Przemyślu, z 2 VI 1991 r., „,Biuletyn Ukrainoznawczy”, 2013-2014, nr 16/17, s. 165-166 (dok. 18).

25 Szerzej: R. Drozd, Ukraincy w Polsce wobec swojej przeszłości (1947-2005), Wydawnictwo Tyrsa, Słupsk-Warszawa 2013, s. 216-226.
} 
narodów. Niewiele w tym zakresie zmieniło wykonanie wielu bardzo ważnych kroków na drodze polsko-ukraińskiego zbliżenia przez prezydentów Polski i Ukrainy ${ }^{26}$.

Brak wyraźnego przełomu w pojednaniu polsko-ukraińskim wskazywał papieżowi Janowi Pawłowi II i hierarchom rzymskokatolickim i greckokatolickim na potrzebę dalszej pracy w tym zakresie. Znaczącym wydarzeniem stała się pielgrzymka Ojca Świętego w Ukrainę w dniach 23-27 czerwca 2001 r., gdzie wszędzie przez Ukraińców był gorąco przyjmowany. Również papież odnosił się do Ukraińców ze szczególną życzliwością. Pielgrzymka ta oprócz charakteru religijnego i społecznego miała także wymiar polsko-ukraińskiego pojednania. Podczas beatyfikacji abpa Józefa Bilczewskiego i ks. Zygmunta Gorazdowskiego we Lwowie powiedział po polsku i ukraińsku: „Czas już oderwać się od bolesnej przeszłości! Chrześcijanie obydwu narodów muszą iść razem w imię jedynego Chrystusa, ku jedynemu Ojcu, prowadzeni przez tego samego Ducha, który jest źródłem i zasadą jedności. Niech przebaczenie - udzielone i uzyskane - rozleje się niczym dobroczynny balsam w każdym sercu. Niech dzięki oczyszczeniu pamięci historycznej wszyscy gotowi będą stawiać wyżej to, co jednoczy, niż to, co dzieli, ażeby razem budować przyszłość opartą na wzajemnym szacunku, na braterskiej wspólnocie, braterskiej współpracy i autentycznej solidarności"27. Zapewne natchniony tymi słowami zwierzchnik Kościoła greckokatolickiego kard. Lubomyr Huzar, zwracając się do Jana Pawła II następnego dnia, na początku liturgii w obrządku greckokatolickimi powiedział: „Może wyda się to dziwne, niezrozumiale i sprzeczne, żeby w chwili wysławienia ukraińskiego Kościoła greckokatolickiego przypomnieć też, iż historia naszego Kościoła w minionym stuleciu znała także ciemne i tragiczne duchowo momenty. Polegały one na tym, że niektórzy synowie i córki ukraińskiego Kościoła greckokatolickiego, ku naszemu ogromnemu żalowi, świadomie i dobrowolnie wyrządzili krzywdę swoim bliźnim spośród swego narodu czy innych narodów. Za nich wszystkich w Twojej obecności, Ojcze Święty, pragnę w imieniu Ukraińskiego Kościoła Greckokatolickiego prosić o przebaczenie Pana Stworzyciela i Ojca nas wszystkich, a także o przebaczenie tych, których w jakiś sposób skrzywdziliśmy my, synowie i córki naszego Kościoła. Żeby już nie ciążyła na nas straszliwa przeszłość i nie utrudniała naszego życia, chętnie przebaczamy tym, którzy w jakiś sposób skrzywdzili również nas"28. Były to bardzo ważne słowa obu hierarchów na drodze do pojednania polsko-ukraińskiego. Jednak nie okazało się to takie proste. Środowiska widzące tylko własną krzywdę nie były skłonne zrozumieć bólu drugiej strony, a tym samym posłuchać swoich duchowych pasterzy. Wymagano nadal od drugiej strony uderzenia się we własną pierś.

Kolejną okazją do przypomnienia Polakom i Ukraińcom o potrzebie pojednania stały się obchody 60. rocznicy zbrodni wołyńskiej. 5 maja 2003 r. ukazał się „List pasterski biskupów metropolii kijowsko-halickiej Ukraińskiego Kościoła greckokatolickiego do braci i sióstr sąsiadujących ze sobą narodów ukraińskiego i polskiego", w którym wezwali do pracy na rzecz pojednania. Dokonali także symbolicznego wyznania winy, mówiąc: „Prawdą jest, że

26 Szerzej: tenże, Prawda i przebaczenie. Meandry polsko-ukraińskiego dialogu, „Ethos”, 2017, nr 2, s. 173-194.

27 Przemówienie Ojca Świętego Jana Pawła II podczas beatyfikacji abp. Józefa Bilczewskiego i ks. Zygmunta Gorazdowskiego we Lwowie, z 26 VI.2001 r., „Peremyśki Archyjeparchialni Widomosti”, 14/2017, cz. 23, s. 158 (dok. 10).

${ }_{28}$ M. Melnyk. Rola Kościoła greckokatolickiego w pojednaniu polsko-ukraińskim, w: Kościót greckokatolicki na Warmii i Mazurach. Wobec doświadczeń przeszłości i przemian społeczno-politycznych w Polsce, red. M. Melnyk, Wydawnictwo Naukowe Uniwersytetu Warmińsko-Mazurskiego, Olsztyn 2006, s. 98-99. 
nas krzywdzono. Lecz prawdą jest także i to, że myśmy krzywdzili"29. Takie stanowisko hierarchów greckokatolickich tworzyło przyjazną atmosferę, aby przelana przed wielu laty krew niewinnych osób stała się zaczynem pojednania.

Główne uroczystości rocznicowe odbyły się we wsi Poryck/Pawliwka, gdzie w 1943 r. dokonano mordu Polaków. Miały one doniosły państwowy charakter, ale także wymiar duchowy i pojednawczy. Prezydenci Aleksander Kwaśniewski i Leonid Kuczma wydali wspólne oświadczenie „O pojednaniu w 60. rocznicę tragicznych wydarzeń na Wołyniu”30 oraz odsłonili pomnik pojednania, a także ofiar tej zbrodni. Z okazji tej rocznicy Jan Paweł II ponownie zabrał głos. Wystosował przesłanie do Polaków i Ukraińców, w którym wezwał, „aby Polacy i Ukraińcy nie pozostawali zniewoleni swymi smutnymi wspomnieniami przeszłości [...] niech spojrzą na siebie nawzajem wzrokiem pojednania. Skoro Bóg przebaczył nam w Chrystusie, trzeba, aby wierzący umieli przebaczyć sobie nawzajem doznane krzywdy i prosić o przebaczenie własnych uchybień, i w ten sposób przyczyniać się do budowania świata, w którym respektuje się życie, sprawiedliwość, zgodę i pokój”’31. Zapewne zawołanie papieża Jana Pawła II zachęcało do dalszego wysiłku. Dali temu wyraz niektórzy hierarchowie i duchowni, jak chociażby abp Józef Życiński, kard Lubomyr Huzar czy ks. kanonik Stanisław Bartmiński. Rozpoczęto również prace nad wspólnym dokumentem biskupów obu obrządków, którego do tej pory nie było, a jedynie deklaracje każdej ze stron.

Dnia 19 czerwca 2005 r. odbyła się na Placu Józefa Piłsudskiego w Warszawie Msza w intencji polsko-ukraińskiego przebaczenia i pojednania. W jej trakcie w obecności hierarchów obu obrządków oraz duchowieństwa i wiernych odczytano „List biskupów greckokatolickich Ukrainy i rzymskokatolickich Polski w intencji wzajemnego przebaczenia i pojednania”. Było to wyraźne nawiązanie do listu biskupów polskich do niemieckich z 1965 r. „Wznieśmy się - czytamy w liście - ponad polityczne poglądy i historyczne zaszłości, ponad nasze kościelne obrządki, nawet ponad naszą narodowość - ukraińską i polską. Pamiętajmy przede wszystkim, że jesteśmy dziećmi Boga. Zwróćmy się do naszego Ojca: «Przebacz nam nasze winy, jako i my odpuszczamy naszym winowajcom». Aby nasza modlitwa była ze wszech miar owocna, powiedzmy wobec siebie słowa: «Przebaczamy i prosimy o przebaczenie»" 32 . Tydzień później w tej samej intencji odbyło się w Lwowie nabożeństwo greckokatolickie w miejscu, gdzie w 2001 r. spotkał się z młodzieżą Ojciec Święty Jan Paweł II. Na nabożeństwie tym także odczytano ten list. Dokument można uważać za zwieńczenie starań Jana Pawła II na rzecz doprowadzenia do polsko-ukraińskiego pojednania. Szkoda, że tego nie doczekał, gdyż zmarł 2 kwietnia 2005 r.

Byłoby naiwnością sądzić, że samo wydanie listu doprowadzi do pojednania obu narodów. Niemniej zrobiono bardzo znaczący krok na tej drodze. Powstał wspólny dokument, czyli potwierdzenie na piśmie woli obu episkopatów rzymskokatolickiego w Polsce

\footnotetext{
29 List pasterski biskupów metropolii kijowsko-halickiej Ukraińskiego Kościoła greckokatolickiego do braci i sióstr sąsiadujacych ze soba narodów ukraińskiego i polskiego, z 5 V 2003 r., „Peremyśki Archyjeparchialni Widomosti”, 14/2017, cz. 23, s. 193 (dok. 15).

30 Wspólne oświadczenie Prezydentów Rzeczypospolitej Polskiej i Ukrainy „, O pojednaniu w 60. Rocznicę tragicznych wydarzeń na Wolyniu”, z 11 VII 2003 r., „Biuletyn Ukrainoznawczy”, 2013-2014, nr 16/17, s. 207-209 (dok. 29).

31 Przestanie Ojca Świętego Jana Pawła II do Polaków i Ukraińców z okazji 60. Rocznicy ukraińsko-polskiego konfliktu zbrojnego na Wolyniu, z 7 VII 2003 r., „Biuletyn Ukrainoznawczy”, 2013-2014, nr 16/17, s. 204 (dok. 27).

32 List biskupów greckokatolickich Ukrainy i rzymskokatolickich Polski w intencji wzajemnego przbaczenia i pojednania, z 26 VI 2005 r., „Peremyśki Archyjeparchialni Widomosti”, 14/2017, cz. 23, s. 262 (dok. 27).
} 
i greckokatolickiego na Ukrainie do przebaczenia wyrządzonych sobie wzajemnie krzywd i pojednania. Wskazywał, że duchowieństwo obu obrządków zaczęło wspólnie kroczyć ku lepszej przyszłości obu narodów. Do tej pory, ze względu na brak wspólnego listu oba episkopaty co prawda kroczyły tą samą drogą, ale nie razem, gdyż składano jedynie deklaracje, bardzo ważne, ale były to jednak oddzielne stanowiska stron. Takim wspólnym przejawem dążenia do pojednania było oficjalne otwarcie 24 czerwca 2005 r. Cmentarza Orląt Lwowskich z udziałem prezydentów Polski i Ukrainy, przedstawicieli władz państwowych i samorządowych oraz dostojników kościelnych, czyli po odczytaniu listu w Warszawie, ale przed jego ogłoszeniem na Ukrainie. Z kolei 13 maja 2006 r. doszło do uroczystego odsłonięcia pomnika pomordowanym Ukraińcom w Pawłokomie (woj. podkarpackie). Natomiast 9 lipca 2008 r., czyli w 65. rocznicę mordów na Wołyniu rzymskokatolicki ordynariusz łucki bp Marcjan Trofimiak wystosował do wiernych list pasterski, w którym wzywał do modlitwy nie tylko za ofiary, ale także za katów ${ }^{33}$.

Jeżeli obchody 65. rocznicy mordów na Wołyniu przebiegły bez sztandarowych deklaracji, to inaczej stało się w ich 70. rocznicę. Było to spowodowane brakiem wyraźnego postępu w procesie pojednania polsko-ukraińskiego, a nawet jego pewnym regresem. Do głosu coraz mocniej zaczęły bowiem dochodzić ugrupowania i osoby niechętne porozumieniu na płaszczyźnie „przebaczamy i prosimy o przebaczenie” (w tym przedstawiciele świata polityki i duchowieństwa), a żądające wyłącznie pokajania się drugiej strony, jak i narzucające jej swoją ocenę tamtych tragicznych wydarzeń z lat wojny i okresu powojennego. Nie dziwi więc kolejne zaangażowanie się hierarchów w proces pojednania. 11 marca $2013 \mathrm{r}$. Synod Kościoła greckokatolickiego wydał specjalne orędzie, w którym potępiono zbrodnie popełnione na Polakach i Ukraińcach oraz zaapelowano o „wypracowanie jednakowej chrześcijańskiej oceny przeszłości”. Zadeklarowano także kontynuowanie dzieła pojednania tych dwóch bratnich narodów ${ }^{34}$.

Do procesu pojednania między Polakami i Ukraińcami przyłączył się Kościół prawosławny, który do tej pory w zasadzie milczał, nie licząc udziału jego przedstawicieli w uroczystościach rocznicowych. 27 marca 2013 r. patriarcha Kościoła Prawosławnego Kijowskiego Patriarchatu Filaret w swoim posłaniu wezwał oba narody do noszenia w sercu słów przebaczamy i prosimy o przebaczenie oraz zwrócił się do Polaków słowami: „my wybaczamy i prosimy was o wybaczenie" ${ }^{35}$. Do wzajemnego przebaczenia i pojednania wezwał Polaków i Ukraińców także zwierzchnik Kościoła prawosławnego moskiewskiego patriarchatu na Ukrainie metropolita Wołodymyr ${ }^{36}$. W tym też duchu orędzie ogłosiła 25 kwietnia 2013 r. Wołyńska Rada Kościołów, skupiająca hierarchów Kościoła prawosławnego patriarchatów moskiewskiego i kijowskiego, Kościoła rzymskokatolickiego oraz

\footnotetext{
33 List pasterski ks. bp. Marcjana Trofimiaka rzymskokatolickiego ordynariusza diecezji luckiej ogłoszony z okazji 65-tej rocznicy tragicznych wydarzeń na Wotyniu, z 9 VII 2008 r., „Biuletyn Ukrainoznawczy”, 2013-2014, nr 16/17, s. 230-232 (dok. 36).

34 Orędzie Synodu Biskupów Kijowsko-Halickiego Arcybiskupstwa Większego Ukraińskiego Kościoła Greckokatolickiego do wiernych $i$ wszystkich ludzi dobrej woli w 70. rocznicę tragedii wolyńskiej, z 11 III 2013 r., „Biuletyn Ukrainoznawczy", 2013-2014, nr 16/17, s. 242-245 (dok. 41).

35 Postanie prawosławnego Patriarchy Kijowskiego i całej Rusi-Ukrainy Filareta w 70. Rocznicę tragedii wolyńskiej, z 27 III 2013 r., „Biuletyn Ukrainoznawczy”, 2013-2014, nr 16/17, s. 247 (dok. 42).

36 Odezwa Ukraińskiego Kościoła Prawostawnego Moskiewskiego Patriarchatu w zwiazku z 70. rocznica tragedii wotyńskiej, z 26 VI 2013 r., „Biuletyn Ukrainoznawczy”, 2013-2014, nr 16/17, s. 267-268 (dok. 48).
} 
greckokatolickiego, a także zielonoświątkowców, baptystów i adwentystów dnia siódmego ${ }^{37}$. Z kolei 24 czerwca Episkopat Kościoła rzymskokatolickiego Ukrainy ogłosił list pasterski, w którym nawoływał do pojednania, przypominając jednocześnie słowa modlitwy: „Ojcze nasz [...] odpuść nam nasze winy, jako i my odpuszczamy naszym winowajcom” i wskazywał też, że do pojednania potrzebne są rachunek sumienia oraz zrozumienie odpowiedzialności, które dotyczy jednostki nie zaś zbiorowości ${ }^{38}$. Tym samym biskupi wzywali, aby nie winić całego narodu za zbrodnie, które uczyniły jednostki.

Punktem kulminacyjnym stało się nabożeństwo za ofiary tragedii odprawione 28 czerwca 2013 r. w cerkwi ojców bazylianów w Warszawie, w którym uczestniczyli hierarchowie rzymskokatoliccy i greckokatoliccy z Polski i Ukrainy, a także prezydent Bronisław Komorowski i przedstawiciele rządu ${ }^{39}$. Po nabożeństwie zwierzchnicy Kościołów rzymskokatolickiego i greckokatolickiego w Polsce oraz na Ukrainie podpisali wspólną deklarację w sprawie tragedii wołyńskiej. „Pragniemy dzisiaj - zapisano w niej - oddać hołd niewinnie pomordowanym, ale i przepraszać Boga za popełnione zbrodnie i raz jeszcze wezwać wszystkich, Ukraińców i Polaków, zamieszkujących zarówno na Ukrainie, jak i w Polsce oraz gdziekolwiek na świecie, do odważnego otwarcia umysłów i serc na wzajemne przebaczenie i pojednanie" ${ }^{40}$. Abp Światosław Szewczuk w imieniu Kościoła greckokatolickiego przeprosił Polaków za zbrodnie popełnione w 1943 r., a abp Józef Michalik w imieniu Kościoła rzymskokatolickiego poprosił Ukraińców o wybaczenie ${ }^{41}$. W ten symboliczny sposób dokonano aktu przeproszenia i wybaczenia. Ewenementem deklaracji w porównaniu z listem z $2005 \mathrm{r}$. było to, że podpisali ją także zwierzchnicy: Kościoła greckokatolickiego w Polsce abp Jan Martyniak oraz Kościoła rzymskokatolickiego na Ukrainie abp Mieczysław Mokrzycki. Tym samym dzieło pojednania zostało przypieczętowane deklaracjami zwierzchników Kościoła rzymskokatolickiego w Polsce i na Ukrainie oraz greckokatolickiego na Ukrainie i w Polsce. Podpisanie tej wspólnej deklaracji przez oba Kościoły można uznać za koniec etapu wzajemnych deklaracji. Formuła ta po prostu uległa wyczerpaniu. Teraz nastał czas na refleksję i ocenę tego, co zostało zrobione ${ }^{42}$. Do pomyślnego zakończenia procesu pojednania potrzeba czasu, ale czasu wypełnionego nowymi formami dialogu, w których działania deklaratywne powinny zostać zastąpione konkretną pracą Polaków i Ukraińców ${ }^{43}$.

Proces pojednania między narodami nie należy do łatwych. Dlatego potrzebni są mężowie stanu i przywódcy duchowi, którzy wskazują drogę do osiągnięcia celu. Tak też jest

37 Orędzie Wolyńskiej Rady Kościołów w 70. rocznicę tragedii wołyńskiej, z 25 IV 2013 r., „Biuletyn Ukrainoznawczy", 2013-2014, nr 16/17, s. 255-258 (dok. 45).

38 List pasterski Rzymskokatolickiego Episkopatu Ukrainy w 70. rocznicę tragedii wolyńskiej, z 24 VI 2013 r., „Peremyśki Archyjeparchialni Widomosti”, 14/2017, cz. 23, s. 320-331 (dok. 38).

39 Warszawa: Panichida $w$ intencji ofiar zbrodni wołyńskiej (OPIS), https://kair.ekai.pl/depesza/478318/show? $\mathrm{q}=$ stefan\% 20batruch (dostęp 30.06.2021).

${ }^{40}$ Wspólna deklaracja biskupów rzymskokatolickich i greckokatolickich z Polski $i$ Ukrainy w sprawie tragedii wołyńskiej w 70. Rocznice wydarzeń, z 28 VI 2013 r., „Biuletyn Ukrainoznawczy”, 2013-2014, nr 16/17, s. 270 (dok. 49).

41 Tamże, s. 356.

42 S. Batruch, dz. cyt., s. 80.

43 Na przykład: Malhowice: modlitwa polskich i ukraińskich duchownych podczas Europejskich Dni Dobrosasiedztwa, https://kair.ekai.pl/depesza/481163/show?q=stefan\%20batruch (dostęp 30.06.2021); Polsko-ukraińska droga krzyżowa na Majdanku, https://kair.ekai.pl/depesza/442850/show?q=stefan\%20batruch (dostęp 30.06.2021); Na Lubelszczyźnie rozpoczęty się Europejskie Dni Dobrosąsiedztwa, https://kair.ekai.pl/depesza/447724/sho$\mathrm{w} ? \mathrm{q}=$ stefan $\%$ 20batruch (dostęp 30.06.2021). 
w przypadku dialogu polsko-ukraińskiego. To właśnie hierarchowie Kościoła rzymskokatolickiego i greckokatolickiego, idąc śladem listu biskupów polskich do niemieckich z 1965 r., zainicjowali jego proces. Nieocenioną w tym zakresie rolę odegrał Ojciec Święty Jan Paweł II, który przy każdej sposobności wzywał Polaków i Ukraińców do pojednania. Nic też dziwnego, że zrodził się pomysł, aby św. Jan Paweł II stał się jego patronem ${ }^{44}$. Śladem hierarchów poszli prezydenci Polski i Ukrainy, ale także organizacje mniejszościowe w obu państwach, jak również wiele osób duchownych i świeckich. Nie oznacza to, że wszyscy opowiadają się za pojednaniem, a jeżeli nawet - to na własnych warunkach. Bezsprzecznie przeszkodą jest odmienna ocena przez wielu Polaków i Ukraińców konfliktu polsko-ukraińskiego lat 40. XX wieku oraz niekiedy wykorzystywanie go dla osiągnięcia celów politycznych. To wzajemne obarczanie się winą nie prowadzi do porozumienia. Dlatego wskazana i obrana przez hierarchów formuła ,przebaczamy i prosimy o przebaczenie” jest jak najbardziej odpowiednia. Nie oznacza to, że proces pojednania polsko-ukraińskiego szybko i bezboleśnie się dokona, ale działalność hierarchów obu Kościołów dała mu solidne fundamenty.

\section{Bibliografia}

\section{Pochodzenie cytowanych dokumentów}

Dokumenty polsko-ukraińskiego dialogu, „Biuletyn Ukrainoznawczy”, 2013-2014, nr 16/17, s. 103-318. Polsko-ukraińskie pojednanie w dokumentach hierarchii oraz duchowieństwa, „Peremyśki Archyjeparchialni Widomosti”, 14/2017, cz. 23, s. 84-415.

\section{Literatura przedmiotu}

Batruch S., Współpraca między Kościołem greckokatolickim i rzymskokatolickim na rzecz pojednania polsko-ukraińskiego, „Peremyśki Archyjeparchialni Widomosti”, 14/2017, cz. 23, s. 48-81.

Borkowicz J., Święty Jan Paweł patronem polsko-ukraińskiego pojednania. Stan posiadania, ryzyko i wyzwania projektu, w: Polacy i Ukraincy. Komunikacja-Dialog-Pojednanie, red. M. Melnyk, Wydawnictwo Collegium Columbinum, Kraków 2020, s. 133-146.

Drozd R., Polityka władz wobec ludności ukraińskiej w Polsce w latach 1944-1989, Wydawnictwo Tyrsa, Warszawa 2001.

Drozd R., Prawda i przebaczenie. Meandry polsko-ukraińskiego dialogu, „Ethos”, 2017, nr 2, s. 173-194.

Drozd R., Problem własności byłej katedry greckokatolickiej w Przemyślu w latach 1946-1996, „Scripta Historica", 2018, nr 24, s. 237-256.

Drozd R., Ukraincy w Polsce wobec swojej przeszłości (1947-2005), Wydawnictwo Tyrsa, Słupsk-Warszawa 2013.

Fedorowicz K., Ukraina w polskiej polityce wschodniej w latach 1989-1999, Wydawnictwo Naukowe UAM, Poznań 2004.

Hałagida I., Między Moskwa, Warszawa i Watykanem. Dzieje Kościoła greckokatolickiego w Polsce w latach 1944-1970, Wydawnictwo „Bazyliada”, Warszawa 2013.

Jasna Góra: konferencja o dialogu polsko-ukraińskim w 30. rocznicę obchodów millenium chrztu Rusi, https://kair.ekai.pl/depesza/562775/show?q=melnyk\%20marek (dostęp 30.06.2021).

Jutro rocznica podpisania deklaracji Kościoła łacińskiego i greckokatolickiego nt. zbrodni wołyńskiej (analiza), https://kair.ekai.pl/depesza/494426/show?q=pojednanie\%20 polsko-ukrai\%C5\%84skie (dostęp 30.06.2021).

Malhowice: modlitwa polskich i ukraińskich duchownych podczas Europejskich Dni Dobrosasiedztwa, https://kair.ekai.pl/depesza/481163/show?q=stefan\%20batruch (dostęp 30.06.2021).

44 J. Borkowicz, dz. cyt., s. 133-146. 
Melnyk M., Aktywność polityczna społeczności ukraińskiej na Warmii i Mazurach, w: Polityczne wymiary etniczności, red. M. Mieczkowska, D. Scholze, Wydawnictwo Dante, Kraków 2009, s. 206-217.

Melnyk M., Deklaracje o pojednaniu polsko-ukraińskim: próba dialogu pamięci?, w: Aksjologia społeczno-polityczna: studia i materiały, red. Z. Kobylińska, M. Melnyk, H. Skorowski, Wydawnictwo Uniwersytetu Kardynała Stefana Wyszyńskiego, Warszawa 2016, s. 187-207.

Melnyk M., Ekumeniczny wymiar dialogu polsko-ukraińskiego, „Pogranicza. Studia społeczne”, 2011, t. 17, nr 2, s. 84-98.

Melnyk M., Milenium chrztu Rusi Kijowskiej w procesie pojednania polsko-ukraińskiego, w: Polacy i Ukraińcy. Komunikacja - Dialog - Pojednanie, red. M. Melnyk, Wydawnictwo Collegium Columbinum, Kraków 2020, s. 99-114.

Melnyk M., Polacy i Ukraińcy. Pojednani Ewangelia, „Edukacja Humanistyczna”, 2017, nr 2, s. 23-31.

Melnyk M., Problem badań nad dialogiem i pojednaniem polsko-ukraińskim, w: W cieniu akcji „Wista”, red. M. Melnyk, Wydawnictwo Uniwersytetu Warmińsko-Mazurskiego, Olsztyn 2008, s. 99-120.

Melnyk M., Rola Kościoła greckokatolickiego w pojednaniu polsko-ukraińskim, w: Kościół greckokatolicki na Warmii i Mazurach. Wobec doświadczeń przeszłości i przemian społeczno-politycznych w Polsce, red. M. Melnyk, Wydawnictwo Naukowe Uniwersytetu Warmińsko-Mazurskiego, Olsztyn 2006, s. 145-156.

Na Lubelszczyźnie rozpoczęty się Europejskie Dni Dobrosąsiedztwa, https://kair.ekai.pl/depesza/447724/show?q=stefan\%20batruch (dostęp 30.06.2021).

Polsko-ukraińska droga krzyżowa na Majdanku, https://kair.ekai.pl/depesza/442850/show? q=stefan\%20batruch (dostęp 30.06.2021).

Polsko-ukraińskie pojednanie w dokumentach hierarchii oraz duchowieństwa, „Peremyśki Archyjeparchialni Widomosti”, 14/2017, cz. 23, s. 84-430.

Ukraińcy w Polsce 1983-1993. Kalendarium. Dokumenty. Informacje, red. M. Czech, Wydawnictwo Tyrsa, Warszawa 1993.

Warszawa: Panichida wintencji ofiar zbrodni wotyńskiej (OPIS), https://kair.ekai.pl/depesza/478318/ show?q=stefan\%20batruch (dostęp 30.06.2021). 